\title{
Notes
}

\section{City of Richmond v. J.A. Croson Co.: A Federal Legislative Answer}

\author{
Margaret E. Deane
}

Last year, in City of Richmond v. J.A. Croson Co., ${ }^{1}$ the Supreme Court once again struggled with the constitutionality of affirmative action. The struggle revolves around the tension inherent in the Fourteenth Amendment, which mandates the elimination of discrimination while simultaneously compelling the equal protection of all people. This tension is apparent where the elimination of discrimination requires that particular groups be treated disparately. Where the effects of discrimination continue to disadvantage a group even after the explicit discriminatory practice has been prohibited, preferential treatment may be necessary to remedy the continued discriminatory impact. In order to restore a disadvantaged minority to real equality, therefore, a government may have to employ a program that bestows remedial benefits on the basis of race. Absent such means, the group may continue to suffer the effects of past discrimination perpetuated by the application of facially neutral laws to the status quo.

Unfortunately, the Croson decision does little to resolve the conflicting mandates of the Fourteenth Amendment. ${ }^{2}$ If anything, the decision perpetuates the tension. The broad directives of the decision recognize the continued need to redress past specific discrimination, implying that the Fourteenth Amendment

1. 109 S. Ct. 706 (1989).

2. Richmond's Minority Business Enterprise (MBE) set-aside program, which allocated a fixed percentage of government contracts to minority owned businesses, was struck down as unconstitutional. 
may occasionally compel disparate treatment. However, the highly restrictive test adopted by the Court to establish the existence of such discrimination, which is required as a prerequisite for the application of race-based remedies, signals an effective intolerance of such programs.

Croson is in conflict with itself. Decisionmakers seeking direction from the Court are left with unclear signals. ${ }^{3}$ This Note recommends that Congress correct the internal contradiction within the Court's opinion and alleviate the potential impairment of remedial action caused by Croson. The federal legislative answer proposed replaces the Court's overly narrow test for determining whether race-based relief is appropriate with a congressional test which seeks to recognize and respond to the lingering effects of past discrimination. The authority for such congressional action rests on the special enforcement powers granted to Congress by section 5 of the Fourteenth Amendment.

\section{CROSON'S CONTRADICTION}

In 1983, the City of Richmond adopted an MBE set-aside program which required primary contractors to subcontract at least thirty percent of their contract work to minority-owned businesses. The program was adopted with the stated purpose of remedying past discrimination. The Supreme Court, however, found that the city had not adequately established past discrimination in its construction industry to justify "race-based relief" under the equal protection clause of the Fourteenth Amendment. ${ }^{4}$

\section{A. The Remedial Mandate}

Justice O'Connor, who authored the majority opinion, explicitly endorsed the constitutionality of race-conscious affirmative remedies in certain circumstances. ${ }^{5}$ She emphasized that a state or local government is not limited merely to correcting discrimination by the governmental unit itself, ${ }^{6}$ but may justify its program by showing that "it had essentially become a 'passive participant' in a system of racial exclusion practiced by elements of the local construction industry."7 She stated that any governmental entity, whether federal, state, or local, has a compelling interest in assuring that its spending does not contribute

3. Confusion over what constitutes sufficient evidence of specific discrimination within a locality may cause the premature dismantling or abandonment of needed MBE programs. The City of Richmond, for example, has discontinued its MBE progam altogether. Yet, the evidence suggests that minority firms are continuing to have difficulty obtaining work in Richmond's construction industry. Since Richmond abandoned its program, the percentage of contracting work subcontracted to minority firms has fallen from $32 \%$ to $11 \%$. Reidinger, Life After Croson, A.B.A. J., Oct. 1990, at 33.

4. Croson, $109 \mathrm{~S}$. Ct. at 723.

5. Id. at 720 .

6. Justice O'Connor deliberately overruled the Court of Appeals which held that Richmond must show that the City itself had discriminated against minority contractors to justify its MBE program. Id.

7. Id. 
to the perpetuation of discrimination. ${ }^{8}$ Once it is shown that the government has become a passive participant, she concluded it "could take affirmative steps to dismantle such a system." "Thus, a government may in some instances remedy the effects of past discrimination through the adoption of a race-based program. To justify use of such a remedy, Justice $O^{\prime}$ Connor stressed that all governments have an interest in ensuring that public monies are used in the furtherance, rather than hindrance, of equal opportunity. ${ }^{10}$

\section{B. The Limitations on the Remedy}

This broad confirmation of the legitimacy of affirmative remedies in some situations contradicts the very narrow threshold test for application of racebased programs set out by the Court later in the opinion. ${ }^{11}$ The city of Richmond relied on the following "findings" to establish the existence of discrimination: a statistical study indicating that, although the city's population was $50 \%$ Black, only $0.67 \%$ of its prime construction contracts had been awarded to minority businesses in recent years; figures establishing that a variety of local contractors associations had virtually no MBE members; the City Counsel's conclusion that the plan was constitutional under Fullilove v. Klutznick, ${ }^{12}$ and the statements of plan proponents indicating that there had been widespread racial discrimination in the local, state, and national construction industries. ${ }^{13}$ The Court, however, rejected the validity of these justifications. Justice O'Connor explained that a generalized assertion of past discrimination did not create a justification for the use of race-based remedies, because such an assertion provided no guidance as to how to determine the scope of the injury or design a remedy tailored to that injury. ${ }^{14}$ While the Court did stress that a government could constitutionally implement a race-based program to remedy specific and identifiable local discrimination, ${ }^{15}$ it found that Richmond's factual record did not constitute sufficient evidence of such discrimination. ${ }^{16}$

The Court also concluded that the city could not rely on "Congress' finding in connection with the set-aside approved in Fullilove that there had been nationwide discrimination in the construction industry."17 The Court had previously established that Congress could take action to correct the effects of past discrimination based on its unique remedial power under section 5 of the

\section{Id.}

9. $I d$.

10. Id.

11. See Stewart, Set-Asides Set Aside, A.B.A. J., Apr. 1989, at 46 (discussing confusion between Croson's broad and narrow standards).

12. 448 U.S. 448 (1980).

13. Croson, 109 S. Ct. at 714.

14. Id. at 723 .

15. Id. at 729 .

16. Id. at 728 .

17. Id. at 726 . 
Fourteenth Amendment. ${ }^{18}$ The Croson Court, however, rejected the argument that national findings could be applied by local governments to justify their MBE programs. The rationale rested on the distinction the Court drew between Congress' broad power under section 5 to remedy "a prior pattern of discrimination" and the states' more limited authorization to correct specific discrimination supported directly by their own spending practices. ${ }^{19}$ While the general congressional finding could continue to provide justification for a federal program, it could not be adopted to justify a state or local MBE program.

The Court's treatment of Richmond's statistical evidence provides insight into the threshold test that must be met to justify the use of race-based relief by a city or state. The Court found that the two statistical groups Richmond relied upon to show that discrimination was present in the local construction industry were not adequately connected..$^{20}$ The city had used the discrepancy between the percentage of contracts awarded to minority firms $(0.67 \%)$ and the relative size of the city's Black population (50\%) to conclude that there had been discrimination against minority contractors. ${ }^{21}$ The Court did not find this to be a relevant comparison and determined that "where special qualifications are necessary, the relevant statistical pool for purposes of demonstrating discriminatory exclusion must be the number of minorities qualified to undertake the particular task."22 Thus the Court concluded that a "qualified contractors" formula, which compared the percentage of minority firms receiving contracts to the percentage of minority firms currently available, was required to establish specific and identified discrimination.

A comparison to the number of minority firms available may be meaningless, however, where minorities are deterred from founding their own firms in the first place because discrimination is known to preclude their success. ${ }^{23} \mathrm{As}$

\footnotetext{
18. Fullilove, 448 U.S. at 483.

19. Croson, $109 \mathrm{~S} . \mathrm{Ct}$ at 727.

20. Id. at 725 .

21. Id. at 714 .

22. Id. at 725 .
}

23. The danger in relying solely on the Court's "qualified contractors" comparison has been described in a recent statement published by a group of prominent constitutional scholars:

Pervasive discrimination does not merely operate at the application stage; its more subtle and perhaps more serious consequence is to deter and discourage members of minority groups from even seeking to enter the market for occupations, business opportunities or homes in certain neighborhoods. This consequence is an especially appropriate target of remedial policies. When courts seek to determine the existence and extent of past discrimination by making statistical comparisons to relevant labor pools, it is critical that such courts recognize the extent to which such discrimination may itself have produced smaller numbers in the comparable minority population. This may be especially important in the area of contracting or subcontracting, where the perceived demand for minority subcontractors may be the determinative factor in minority business formation. Without such consideration of deterrence, courts might well create a Catch-22 for cities seeking to implement sound affirmative action policies for subcontracting. 
a result, application of the "qualified contractors" test will tend to hide the continued existence of discriminatory impact on a group. This test may thus preclude the use of race-based remedies where the continued effects of past discrimination are most pronounced. This result is at odds with the broad direction outlined earlier in the opinion, which generally acknowledges the need for remedies that redress the effects of past discrimination.

\section{The Practical Contradiction}

While the Court's statistical comparison is unlikely to identify the continuing effects of past discrimination, the use of nonstatistical evidence is fraught with political danger. ${ }^{24} \mathrm{It}$ is likely that politicians will be hesitant to admit that their administration has contributed to past discrimination, even through mere acquiescence. ${ }^{25}$ Such an admission could be politically detrimental to individual representatives. Naturally, it is easier and politically safer to attribute current problems to broad societal defects than to specific acts of discrimination. Politicians are more likely to implement beneficial programs if they can do so without impugning their own policy. ${ }^{26}$ Documentation of identified discrimination may work exclusively as a disincentive to vote-conscious politicians, rather than as an incentive to redress past wrongs. Consequently, a rule that requires a direct, nonstatistical showing of past or present specific discrimination may create an insurmountable obstacle to remedial action within the context of practical political considerations.

The reality of American life is that discrimination and its effects continue to play a dominant role in our society. ${ }^{27}$ The need for government to eliminate this discrimination also continues. ${ }^{28}$ This is especially true in the construction industry, where the effects of discrimination continue to have a significant

depressive effect of discrimination on the incentives of racial minorities and women to participate in employment and government programs has been judicially recognized.") (citing Dothard v. Rawlinson, 433 U.S. 321, 330 (1977) (employment); United Jewish Orgs. v. Carey, 430 U.S. 144, 163-64 (1977) (voting)).

24. See U.S. v. Marengo County Comm'n, 731 F.2d 1546, 1558 (11th Cir. 1984), cert. denied, 469 U.S. 976 (1984) ("Inquiry into the motives of elected officials can be both difficult and undesirable, and such inquiry should be avoided when possible.") (footnote omitted).

25. See Constitutional Scholars' Statement, supra note 23, at 1714 (courts should not require that racebased remedies be predicated on "compromising public admissions").

26. See Lawrence, The Id, the Ego, and Equal Protection: Reckoning with Unconscious Racism, 39 STAN. L. REV. 317, 326 (1987) ("W]ithout the necessity for blame, our resistance to accepting the need and responsibility for remedy will be lessened.").

27. See id. at 322 ("Americans share a common historical and cultural heritage in which racism has played and still plays a dominant role."); Delgado, Derrick Bell and the Ideology of Racial Reform: Will We Ever Be Saved? (Book Review), 97 YALE L.J. 923, 928-47 (1988) (Black story about America is story of racism and exclusion).

28. Croson, $109 \mathrm{~S}$. Ct. at 721 ("[W]e [do not] view "racial discrimination as largely a phenomenon of the past' or [believe] that 'government bodies need no longer preoccupy themselves with rectifying racial injustice." ") (quoting Marshall, J., dissenting). 
impact. ${ }^{29}$ There is evidence that government procurement practices, while raceneutral on their face, may actually result in the perpetuation of private discrimination. ${ }^{30}$ Further, the nature of the construction industry creates a unique opportunity for government bodies to effect change. ${ }^{31}$

The Croson opinion is in conflict with itself. It suggests a need for raceconscious remedial action to redress the effects of past discrimination. Yet it requires a test which is likely to prevent such redress where it is needed most. Congress can resolve this tension and affirmatively remedy the effects of past discrimination that continue to disadvantage minorities.

\section{A CONGRESSIONAL SOLUTION}

Congress should revise the test that the Court set out as a prerequisite for race-conscious remedial action. Specifically, Congress should replace the "qualified contractors" test with one that is better suited to identifying the continuing effects of past discrimination. Such a test would correct the contradiction within the Croson decision, thereby fulfilling the overall spirit of Croson.

29. In addition to the normal problems inherent in starting a new business, MBE's must also overcome extra financial hurdles resulting from racial barriers in obtaining financing. See R. GLOVER, MRNORTY ENTERPRISE IN CONSTRUCTION 40-42,57-60,73 (1977). This discrimination is especially destructive in light of the greater dependency minority contractors tend to have on long term debt, a dependency which derives from the baseline economic disadvantages confronting most minorities. See id. at $40-44$. Further, prejudice and institutional discrimination which persist in the bonding market significantly reduce the ability of minorities to secure the bonding essential to qualify for government contracts. See id. at 57-60. Not only do financing and bonding requirements tend to perpetuate the effects of past and lingering discrimination, but the historical lack of access to training and apprenticeship programs has inhibited the initial entry of minorities into the construction industry. See id. at 116-17; see e.g., Local 28 of Sheet Metal Workers Int'l Ass'n v. EEOC, 478 U.S. 421,427 (1986) (evidence found that Blacks had been persistently excluded from union and apprenticeship programs).

30. Public contracts typically have more stringent bonding requirements than equivalent contracts in the private sector. See R. GLOVER, supra note 29 , at 73 . As a result, the harm caused to minorities by private discrimination in the bonding industry is exacerbated because the contracting requirements force greater reliance on the bonding market for access to prized government contracts. Id. Consequently, merely raceneutral government procedures not only fail to correct the effects of past discrimination, but can actually perpetuate the effects of nongovernmental discrimination. See Fullilove, 448 U.S. at 478 ("Congress had abundant historical basis from which it could conclude that traditional procurement practices, when applied to minority businesses, could perpetuate the effects of prior discrimination."); Rosenfeld, Decoding Richmond: Affirmative Action and the Elusive Meaning of Constitutional Equality, 87 MICH. L. REV. 1729, 1766 (1989) ("[S]eemingly race-neutral factors invoked by the Court remain so only when viewed in isolation. In the context of systematic racial discrimination, these factors take on another light, as they are likely to exacerbate the relative disadvantages experienced by victims of racism.").

31. In the construction industry, government contracting work is typically "one of the few available routes to breaking into construction." R. GLOVER, supra note 29 , at 73 (quoting "an established white contractor"). Given the limited opportunity for entry into the industry, it is imperative that access to government contracting be affirmatively kept open. 


\section{A. Why Congress?}

Experience with the Voting Rights Act of 1965 suggests that a legislative solution is preferable to a judicial approach. Prior to the adoption of the Voting Rights Act, discriminatory voting practices could only be identified and eliminated on a case-by-case basis. ${ }^{32}$ This required extensive and inefficient commitments of time and resources for each case, with the result that each enforcement action did little to rectify the overall problem. ${ }^{33}$ The Voting Rights Act, on the other hand, identified discriminatory practices automatically and allowed systemic change to be implemented..$^{34}$ Congress could do the same with respect to the adoption of MBE set-aside programs and eliminate the need to develop factual records of specific discrimination on a case-by-case or city-bycity basis. ${ }^{35}$

Where discrimination is determined to exist, a systematic program could be applied to eliminate the effects of that discrimination in a consistent and geographically uniform fashion, irrespective of local ability or initiative to adopt necessary race-based remedies under the Croson standard. ${ }^{36}$

Finally, a federal solution would lift the burden of responsibility for indentifying discriminatory effect in the construction industry out of the local political arena and place the burden on federal legislators, who are in a better position to develop a fair and efficient standard. ${ }^{37}$ An independent statistical test developed by Congress would relieve politicians at the state and local level from the

32. See Note, Civil Rights-Voting Rights Act of 1965, 44 TEX. L. REV. 1411, 1412 (1966).

33. Id.

34. Id.

35. Fullilove, 448 U.S. at 476-77 (Congress acted within its competence when it determined that pattern of disadvantage and discrimination within construction industry was national in scope and that nationally applied federal program was necessary to effectively redress effects of such pattern); Oregon v. Mitchell, 400 U.S. 112, 134 (1970) (recognized that discrimination on basis of race is problem of national scope affecting all parts of country and that, as such, national solution undertaken by Congress is appropriate solution).

36. Further, Congress has the broad perspective implicit in national governance to recognize that full equality requires not only equal treatment devoid of discriminatory intent, but also equal participation in the economic power structure which shapes our political system. See Fiss, Groups and the Equal Protection Clause, 5 PHIL. \& PUB. AFF. 107, 152 (1976) (Blacks' economic position as perpetual underclass has contributed to their political disempowerment). Just as Congress recognized that discrimination in voting must be eradicated to ensure equal protection in the political process, Congress could acknowledge that expanded participation in the economic system through government contracting allocations is a necessary step toward greater equality in the society at large. See Fullilove, 448 U.S. at 465-66 ("The presumption must be made that past discriminatory systems have resulted in present economic inequities. In order to right this situation, the Congress has formulated certain remedial programs designed to uplift those socially or economically disadvantaged persons to a level where they may effectively participate in the business mainstream of our economy.") (quoting H.R. REP. No, 468, 94th Cong., 1st Sess. 1-2 (1975)). Cf. W. WILSON, THE TRULY DISADVANTAGED 110 (1987) (arguing that race-specific policies do little to help truly disadvantaged Blacks and therefore may actually obscure real issues of racial dominance).

37. Congress' fact-finding authority and abilities far outstrip those of state and local governments. See Cox, The Role of Congress in Constitutional Determinations, 40 U. CDN. L. REV. 199, 229 (1971) (usual judicial deference to legislative judgments of fact combined with special section 5 enforcement powers make federal finding of fact superior to finding of state legislature or of court). 
necessity of identifying and documenting specific instances of discrimination within their own government structures. ${ }^{38}$

\section{B. The Legislative Proposal: A New Test}

\section{The Proposed Statute}

(a) To assure that access to publicly funded contracts is not inhibited on the basis of race or color, each state and local government which is found to exhibit discrimination in the award of government contracts under subsection (b), may [shall] adopt a minority business enterprise set-aside program. The program must be structured to ensure that a sufficient percentage of all government contracting expenditures shall be expended for minority business enterprises to redress the discrimination found to exist under subsection (b). For purposes of this section, the term 'minority business enterprise' means a business at least fifty percent of which is owned by minority group members. For purposes of the preceding sentence, 'minority group members' will be defined on a case-by-case basis to include the minorities historically disadvantaged in the state or locality. Nationally, historically disadvantaged groups have included African-Americans, Latinos, Asians, and Native Americans. There must be evidence that a national minority group has had local historical presence for purposes of interpreting 'historically disadvanged' within this section. Such evidence will be derived from U.S. Census information, or in the absence of relevant Census data, from other reliable and accepted population surveys. This program shall include a waiver provision to be granted where compliance with the setaside requirement is shown to be impossible. The implementation of the program shall be limited to five-year renewable periods accommodating a periodic review schedule. The program may [shall] be renewed until such time as the state or local government comes into compliance with subsection (b).

(b) The existence of specific discrimination within a state or locality will be established where the ratio of the number of nonminority contracting firms to the nonminority population exceeds the ratio of the number of minority contracting firms to the minority population by a statistically significant factor.

(c) The Equal Employment Opportunity Commission is empowered to monitor discrimination in the award of state and local government

38. In addition to the political disincentive, a nonstatistical test may prove unduly burdensome for local governments. See Taylor, The Equal Protection Dilemma of Voluntary State and Local Set-Aside Programs for Minorities and Women, 27 Hous. L. REV. 45, 77 (1990) (comprehensive record now required under Croson to justify adoption of MBE set-aside program is burdensome for resource-limited governmental agencies). Cf. Constitutional Scholars' Statement, supra note 23, at 1713 ("[T] he [Croson] Court has also rejected the notion that local governments may implement such remedial programs only if they bear the tortuous and often divisive burden of documenting specific incidents of purposeful past discrimination on identified occasions."). 
contracts as set forth in subsection (b). [The Attorney General is empowered to bring enforcement actions pursuant to noncompliance with subsections (a) and (b). Minority group members harmed by the existence of continued discriminatory impact as identified in subsection (b) are also empowered to bring private enforcement actions pursuant to noncompliance with subsections (a) and (b).]

The congressional program outlined above employs a new statistical test which can be applied to determine whether discrimination exists in the construction industry of a particular region. State and local governments in regions failing to satisfy this test would adopt a MBE set-aside program tailored to the local problem. Congress has the Court's authorization to remedy the effects of discrimination not caused directly by the federal government, ${ }^{39}$ and it would be comingling this initiative with the interests of state and local governments in not supporting discrimination with their purses. To a large extent, Congress would be building on the Court's directives.

The point at which the proposed standard diverges from the Court's standard for using race-based remedies centers on the use of statistical comparisons. The proposed legislation attempts to incorporate the hidden effects of past and present discrimination, which the "qualified contractors" test neglects to address. The comparison is between two ratios, a nonminority ratio and a minority ratio. Each ratio is calculated by dividing the number of firms by the relevant populations. Thus, the number of nonminority firms is divided by total nonminority population, and the number of minority firms is divided by the total minority population..$^{40}$ The resulting figures are then compared, and if the nonminority ratio is significantly higher than the minority ratio, indicating that a higher percentage of the nonminority population is involved in the construction industry than the percentage of the minority population involved, discrimination is determined to exist. ${ }^{41}$

The design of the congressional standard is derived from sections 4(a) and 4(b) of the Voting Rights Act ${ }^{42}$ which were intended to prohibit discriminatory state voting procedures. Congress developed a uniform statistical standard to serve as evidence of unlawful state practices. If a state falls below the statute's statistical standard and it employs a voter qualification test, there is a presumption that discrimination exists in that state's voting system. A finding that less than half of the people in the state registered or voted in a past presidential election signals that the qualification test works to create a discriminatory exclusion of minorities. Insufficient voter turnout is correlated with voter

39. Fullilove, 448 U.S. at 478.

40. Compare \# of nonminority firms to \# of minority firms nonminority population minority population

41. The ratio avoids the simplistic comparison rejected by Croson, which measured the percentage of contracts given to minority firms directly against the minority population percentage, and instead creates a comparison of the proportional involvement of each relevant group in the industry.

42. 42 U.S.C. \& 1973b (1982). 
exclusion. Thus Congress employed a result-based statistical screening formula to generate evidence of unlawful discrimination. The proposed statute mirrors this statistical test and uses it to identify discrimination in the construction industry.

Congress did not use the "qualified contractors" test for implementation of its own MBE set-aside program. ${ }^{43}$ Further, the Court acknowledged congressional authority under section 5 to use a broader statistical comparison to establish the existence of discrimination ${ }^{44}$ than the Croson "qualified contractors" comparison which state and local governments were required to satisfy. ${ }^{45}$ By developing a standard that goes beyond the Court's "qualified contractors" test, this legislation begins to incorporate the hidden exclusionary effects of discrimination. The comparison ratio outlined above should identify discrimination that has resulted in the exclusion of minorities from initial entry into the construction industry and allow the camouflaged consequences of past discrimination to be redressed.

\section{CONStitutionality OF the PROPOSAL}

Congress occupies a special role in the enforcement of the Fourteenth Amendment. This role includes the duty to redress the effects of unlawful discrimination and, where necessary, impose appropriate remedies. Thus Congress can and should develop legislation to remedy historical discrimination in the construction industry.

\section{A. The Proposal is Largely Consistent with Croson}

The majority of the provisions within the proposed legislation are derived directly from Fullilove and Croson. For example, the requirement "that a sufficient percentage of all government construction expenditures shall be expended for minority business enterprises to redress the discrimination found to exist under subsection (b)" is intended to ensure that the percentage of contracts set aside is sufficent to effectively remedy the problem, but not so large as to go beyond what is needed to "cure the effects of prior discrimination." ${ }^{.46}$ The Fullilove Court upheld the congressional ten percent set-aside only after it determined that the impact on access to government contracts by nonminorities would be "light" and therefore did not impose an unnecessary

43. Fullilove, 448 U.S. at 459 (relied on comparison of percentage of minority firms receiving federal contracts to percentage of minorites in population as whole).

44. Croson, 109 S. Ct. at 719.

45. Id. at 725 .

46. Fullilove, 448 U.S. at 484. 
burden on a particular racial group. ${ }^{47}$ Thus, the set-aside provision in the proposed legislation allows for flexibilty in adopting a percentage requirement that will balance the need for redress of discrimination with the Court's concern. that the impact on nonminorities not be unnecessarily burdensome.

The proposed legislation also incorporates the Croson directive that racebased remedial programs be "narrowly tailored." 48 There is a provision defining "minority" on a local basis, which addresses the Court's concern about overinclusiveness. The Court found that Richmond's program was not narrowly tailored because it included, as beneficiaries, minority groups that had no historical connection to Richmond. ${ }^{49}$ By defining "minority" to include only those groups actually disadvantaged by past discrimination within a locality, the proposed legislation is not overinclusive. The waiver provision is included in response to the Court's finding in Fullilove that, absent the federal government's waiver provision, the set-aside legislation would not have passed muster because of the potential for program misapplication and unreasonable price blackmailing..$^{50}$ The final "narrow tailoring" provision requires that the program authorization be limited to five-year periods to ensure that periodic reexamination will occur. ${ }^{51}$ This limited duration provision should prevent the continuation of programs past the point where the effects of discrimination continue to be felt..$^{2}$

\section{B. Congressional Power to Override}

The proposed solution siginificantly diverges from the Court's interpretation as to when race-based remedies may be employed. It might be argued that the alternative test proposed effectively overrides the constitutional holding in Croson. To the extent the legislation does overrule Croson, Congress may legitimately do so under its unique section 5 power to enforce the Fourteenth Amendment. An examination of the history, interpretation, and use of this power since its creation with the adoption of the Civil War Amendments provides a basis for this assertion.

47. Id. at 484-85. The Court also concluded that "it was within congressional power to act on the assumption that in the past some nonminority businesses may have reaped competitive benefit over the years from the virtual exclusion of minority firms from these contracting opportunities." Id. at 485.

48. Croson, 109 S. Ct. at 728 .

49. Id.

50. Fullilove, 448 U.S. at 487 . See also Days, supra note 23, at 484 ("[T]he program should contain explicit provisions for waiver of the specified percentages in cases where it can be established that they are unattainable or unrealistic despite best efforts.").

51. The Equal Employment Opportunity Commission will conduct the periodic review under its monitoring responsibilities outlined in subsection (c) of the proposed act. The Commission has analogous enforcement duties under Title VII of the Civil Rights Act of 1964 and has developed expertise to monitor employment discrimination of both private and governmental employers. 42 U.S.C. $\S 2000 \mathrm{e}-5$ (1982).

52. See Days, supra note 23 , at 484 (recommending governments specify program duration). 


\section{The Section 5 Power}

A central goal in adopting the Fourteenth Amendment was to provide Congress with a powerful tool that could be used to shape and support the propagation of equal protection ideals. ${ }^{53}$ The country was recovering from the wounds inflicted by the Civil War, and the federal government was charged with the duty of developing and implementing a plan of Reconstruction that would move the country towards freedom and equality for Black Americans. ${ }^{54}$ The Fourteenth Amendment ensured that Congress had a constitutional basis to pursue this mandate to protect fundamental rights. ${ }^{55}$

The amendment was drafted primarily by Representative Bingham of Ohio, who set out to create a constitutional basis for the Civil Rights Act of $1866 .{ }^{56}$ The distinguishing feature of Bingham's proposal ${ }^{57}$ and the real strength of the amendment was the express grant of an enforcement power to Congress. ${ }^{58}$ Both proponents and opponents of the bill recognized the broad potential for expansion of Congressional power in section $5 .^{59}$

Thus, the Fourteenth Amendment contains both a direct limitation on the states (section 1) and the grant of enforcement power to Congress (section 5). Professor Bohrer has developed a helpful theory to explain the connection between these two provisions. ${ }^{60}$ Bohrer suggests, "Congress cannot possibly 'enforce' section 1 of the Fourteenth Amendment without first interpreting the provisions to be enforced. [Congress has] primacy in enforcement, granted by section 5, [and this] necessarily entails primacy in interpretation." 61 Thus, Congress can interpret section 1 to prohibit the perpetuation of the effects of past discrimination even where the Court has previously interpreted section 1 to preclude redress for the continuing effects of past discrimination.

Modern judicial interpretation of the enforcement powers granted to Congress by the Civil War Amendments began with challenges to the Voting Rights Act of $1965 .{ }^{62}$ The first of these was South Carolina v. Katzenbach ${ }^{63}$ The

53. The Framers of the Fourteenth Amendment had four general goals: to guarantee certain civil liberties against state action; to apply these liberties equally to all citizens, regardless of race; to give Congress wide power to enforce the amendment and expand civil rights; and to make the federal government the ultimate guarantor of individual civil rights. See 2 R. ROTUNDA, J. NOWAK \& J. YOUNG, TREATISE ON CONSTTUUTIONAL LAW: SUBSTANCE AND PROCEDURE § 18.7, 378-79 (1986).

54. See C. FAIRMAN, RECONSTRUCTION AND REUNION 1274-75 (1971).

55. See H. FLACK, THE ADOPTION OF THE FOURTEENTH AMENDMENT 59, 92,96 (1908).

56. Id. at $30-32,79$.

57. Other proposals considered by the Committee of Fifteen did not include enforcement provisions. See C. FAIRMAN, supra note 54, at 1280.

58. "The Congress shall have power to enforce, by appropriate legislation, the provisions of this article." U.S. CONST. amend. XIV, §5.

59. See H. FLACK, supra note 55, at 136-39.

60. See Bohrer, Bakke, Weber and Fullilove: Benign Discrimination and Congressional Power To Enforce the Fourteenth Amendment, 56 IND. L.J. 473, 492 (1981).

61. Bohrer, supra note 60, at 493. See also Buckley v. Valeo, 424 U.S. 1, 121 (1976) (powers delegated to three branches are not hermetically sealed from one another).

62. Pub. L. No. 89-110, 79 Stat. 437 (1965). 
State of South Carolina challenged section 4(a) and 4(b) of the $\mathrm{Act}^{64}$ on the basis that these provisions constituted an invasion of a state's traditional power to regulate voter qualifications and election procedures. Chief Justice Warren applied a deferential standard for review of federal voting rights legislation, which required simply that the challenged measure be appropriate, be adapted to the end of eliminating voting discrimination, and not be prohibited by any other constitutional provision. ${ }^{65}$ The Court emphasized Congress' primary role in enforcement of the Fifteenth Amendment ${ }^{66}$ and Congress' broad discretion to select those remedies it finds likely to be most efficacious without regard to existing judicial remedies. ${ }^{67}$ The Court has interpreted the scope of enforcement powers under section 5 of the Fourteenth Amendment and section 2 of the Fifteenth Amendment to be essentially coextensive. ${ }^{68}$

In Katzenbach v. Morgan, ${ }^{69}$ a case drawing upon the rationale of South Carolina v. Katzenbach, the Court solidified a broad interpretation of Congress' section 5 power. Morgan involved a challenge to section 4(e) of the Voting Rights Act of $1965,{ }^{70}$ which forbade the use of literacy requirements for voters educated in Puerto Rico. Enactment of the legislation followed on the heels of Lassiter $v$. Northampton Election Board, ${ }^{71}$ which held that literacy tests did not violate the Fourteenth or Fifteenth Amendment absent some showing of discriminatory application. ${ }^{72}$ The Morgan Court upheld congressional authority to adopt section 4(e), despite its previous contradictory holding in Lassiter. ${ }^{73}$

Section $4(\mathrm{e})$ was challenged by the state of New York, where such tests were required, on the basis that "Congress [had] exceeded the powers granted to it by the Constitution and therefore usurped powers reserved to the States

63. 383 U.S. 301 (1966).

64. Section 4(a) prohibits the use of voting tests or devices in states that, under section 4(b), have less than $50 \%$ of the persons of voting age registered. See supra note 42 and accompanying text.

65. Katzenbach, 383 U.S. at 326.

66. "[T] Amendment] rights . ..." Id. (citing Ex Parte Virginia, 100 U.S. 339, 345 (1880) ("It is the power of Congress which has been enlarged.")).

67. Katzenbach, 383 U.S. at 327.

68. See James v. Bowman, 190 U.S. 127, 136 (1903) (Fifteenth Amendment enforcement power similar to that granted by Fourteenth Amendment); Burt, Miranda and Title II: A Morganatic Marriage, $1969 \mathrm{~S}$. Ct. Rev. 81, 103 (enforcement provisions of Fifteenth and Fourteenth Amendments are identical).

69. 384 U.న. 641 (1966).

70. Pub. L. No. $89-110, \S 4(e), 79$ Stat. 437,439 (1965) (currently codified at 42 U.S.C. $\$ 1973 b(e)(1)$ (1982)).

71. 360 U.S. 45 (1959)

72. See Carter, The Morgan "Power" and The Forced Reconsideration of Constitutional Decisions, 53 U. CHI. L. REV. 819, 820 (1986).

73. Morgan, 384 U.S. at $648-49$ ("A construction of $\$ 5$ [of the Fourteenth Amendment] that would require a judicial determination that the enforcement of the state law precluded by Congress violated the Amendment, as a condition of sustaining the congressional enactment, would depreciate both congressional resourcefulness and congressional responsibility for implementing the Amendment. It would confine the legislative power in this context to the insignificant role of abrogating only those state laws that the judicial branch was prepared to adjudge unconstitutional, or of merely informing the judgment of the judiciary by particularizing the 'majestic generalities' of $\$ 1$ of the Amendment.") (footnote omitted). 
by the Tenth Amendment." ${ }^{\text {"74 }}$ The Court held that the provision was "a proper exercise of the powers granted to Congress by section 5 of the Fourteenth Amendment.."75 Relying on Ex Parte Virginia, ${ }^{76}$ Justice Brennan, writing for the majority, rejected the claim that section 4(e) could not be sustained unless the Court itself found that the literacy requirement forbidden by section 4(e) violated the Fourteenth Amendment. ${ }^{77}$ The Court further held that Congress has an independent power to identify discrimination and to select the appropriate means to remedy it. ${ }^{78}$ Finally, the Court held that its review of the exercise of Fourteenth Amendment congressional enforcement power is limited to an attempt to "perceive a basis" for the congressional action. ${ }^{79}$

There is heated debate among constitutional scholars as to the extent Morgan and its progeny provide precedent for congressional authority to explicitly overrule a Supreme Court decision in the realm of equal protection jurisprudence. ${ }^{80}$ However, this debate may be irrelevant given Congress' past effective override of a constitutional interpretation issued by the Court in the voting rights area and the Court's subsequent acquiescense to the congressional override. ${ }^{81}$

\section{Exercise of Section 5 Power}

Congress exercised its section 5 prerogative with the adoption of the Voting Rights Act Amendments of 1982, ${ }^{82}$ amending section 2 of the Voting Rights Act and effectively overriding the Court's interpretation of a constitutional

74. Id. at 646 .

75. Id. This case was decided under the Fourteenth Amendment rather than the Fifteenth Amendment because Congress explicitly enacted the challenged statute to secure rights protected by the Fourteenth Amendment. 42 U.S.C. § 1973b(3) (1982).

76. 100 U.S. $339,345-46$ (1879).

77. Morgan, 384 U.S. at 648.

78. Id. at 653 .

79. Id.

80. Compare Burt, supra note 68 and Carter, supra note 72 and Cox, supra note 37 with Brest, Congress as Constitutional Decisionmaker and Its Power to Counter Judicial Doctrine, 21 GA. L. REv. 57 (1986) and Emerson, The Power of Congress to Change Constitutional Decisions of the Supreme Court: The Human Life Bill, 77 Nw. U.L. REV. 129 (1982) and Estreicher, Congressional Power and Constitutional Rights: Reflections on Proposed "Human Life" Legislation, 68 VA. L. REV. 333 (1982). However, this scholarly debate may obscure the real issues underlying the proposed legislation. The more interesting focus, as identified by Professor Carter in his article on the Morgan power, lies not in the technical legal approach wherein a justification for adoption of controversial legislation is built upon the foundation of potentially debatable constitutional theory, but rather in the examination of the moral or political value of the right sought to be expanded or limited by the Morgan power. See Carter, supra note 72, at 846 ("If we persist in burying arguments over policy under an avalanche of constitutional jargon, then those who want to speak most closely to the point-whether the proposed legislation is good or bad-will essentially be denied a hearing.").

81. See infra Section V.B.2.

82. Pub. L. No. 97-205, 96 Stat. 131 (codified as amended at 42 U.S.C. $\S \S 1973,1973 b, 1973 a a-1 a$, 1973aa-6 (1982)). 
provision..$^{83}$ The amendments sought to change the constitutional standard established by the Court in City of Mobile v. Bolden for determining whether discrimination was present in Mobile's at-large voting system. ${ }^{84}$ In Bolden, the Court interpreted the equal protection clause to require that a racial vote dilution claimant must prove discriminatory purpose to establish a violation of constitutional law. ${ }^{85}$ The congressional amendments created a new resultoriented test. ${ }^{86}$

In Bolden, the Court had specifically rejected the use of a results-oriented test and found that a complete absence of minority representation on Mobile's City Commission did not justify a finding of discrimination within the reach of the Fourteenth or the Fifteenth Amendment. ${ }^{87}$ Thus, Congress overrode the Court's pure intent requirement by including effect or result-based criteria in the determination of whether the qualification or practice is discriminatory and therefore unlawful. ${ }^{88}$ In effect, Congress reinterpreted what constituted a violation of the Fourteenth and Fifteenth Amendments in response to a judicial interpretation it found to be incorrect.

In United States v. Marengo County Commission, ${ }^{89}$ defendants challenged the constitutionality of the Voting Rights Act Amendments of 1982. Defendants argued that Congress overextended its enforcement powers when it enacted the amendments, and had, in effect, "usurped the power of the Supreme Court ... by attempting to overrule Mobile v. Bolden." 90 The Eleventh Circuit found that although Congress had considered specifically the impact and binding nature of the Court's constitutional interpretation, it had relied on its own separate and independent "power to enforce the Civil War Amendments."11 The court further determined that the congressional decision to adopt a resultsbased test for voting discrimination was a legitimate exercise of its authority

83. Congress relied on its analogous Fourteenth and Fifteenth Amendment enforcement powers to enact this legislation. See Hartman, Racial Vote Dilution and Separation of Powers: An Exploration of the Conflict Between the Judicial "Intent" and the Legislative "Results" Standards, 50 GEO. WASH. L. REV. 689, 740 (1982).

84. 446 U.S. 55 (1980).

85. Bolden, 446 U.S. at 66 . ("[O]nly if there is purposeful discrimination can there be a violation of the Equal Protection Clause of the Fourteenth Amendment."). The Court went on to find that a showing of "disproportionate effects" does not suffice as evidence of discriminatory purpose, id. at 67 , and that reliance on such a test to establish racial discrimination "is not consistent with the meaning of the Equal Protection Clause." Id. at 67-68.

86. See Hartman, supra note 83 , at 739.

87. Bolden, 446 U.S. at 71.

88. "In Bolden, a plurality of the Supreme Court broke with precedent and substantially increased the burden on plaintiffs in voting discrimination cases by requiring proof of discriminatory purpose. The Committee has concluded that this intent test places an unacceptably difficult burden on plaintiffs. It diverts the judicial injury [sic] from the crucial question of whether minorities have equal access to the electoral process to a historical question of individual motives. In our view, proof of discriminatory purpose should not be a prerequisite to establishing a violation of Section 2 of the Voting Rights Act." S. REP. No. 417, 97th Cong., 2d Sess. 16 (1982).

89. 731 F.2d 1546 (11th Cir. 1984), cert. denied, 469 U.S. 976 (1984).

90. Id. at 1556.

91. Id. (emphasis in the original). 
to enforce both the Fourteenth and Fifteenth Amendments. ${ }^{92}$ The Supreme Court declined to review Marengo on petition for certiorari and thereby supported the lower court's determination that Congress possesses an independent power to interpret and enforce the Fourteenth Amendment even where it acts to overrule a prior Supreme Court holding. ${ }^{93}$

Congress could similarly override the Croson Court's constitutional interpretation of what constitues a record of specific discrimination. In the same way that Congress found the intent standard adopted by the Court in Bolden to be inordinately difficult and to preclude the redress of past voting discrimination under the Fourteenth and Fifteenth Amendments, ${ }^{94}$ Congress could override Croson's "qualified pools" standard to eliminate any unnecessary barriers to the adoption of MBE set-aside programs and to ensure that the effects of past discrimination are redressed within the construction industry. ${ }^{95}$ As in the case of the 1982 Amendments, the authority for such action lies in Congress' special Fourteenth Amendment enforcement powers.

It has been argued that the 1982 amendments constituted a mere modification of judicial statutory interpretation, rather than a congressional override of a constitutional holding. ${ }^{96}$ While such an assertion fits well with the rhetoric that serves politicians seeking passage of needed legislation, an examination of the Bolden decision and the changes wrought by the amendments shows the superficiality of such an argument. The Bolden Court explicitly dismissed the statutory claim on the ground that it added nothing to the plaintiff's case, and immediately went on to interpret what it seemed to consider the more central issue: whether Mobile's at-large voting system violated either the Fourteenth or the Fifteenth Amemdment. ${ }^{97}$ Thus, the Court arrived at a conclusion as to what constituted voting discrimination under the Civil War Amendments, and in so doing clearly described its task as constitutional, not statutory, interpretation. ${ }^{98}$ Congress directly contradicted this interpretation and adopted the inter-

92. Id. at 1556-57.

93. Cert. denied, United States v. Marengo County Comm'n, 469 U.S. 976 (1984).

94. Congress found "(1) that the difficulties faced by plaintiffs forced to prove discriminatory intent through case-by-case adjudication create a substantial risk that intentional discrimination barred by the Fourteenth and Fifteenth Amendments will go undetected, uncorrected and undeterred unless the results test proposed for section 2 is adopted; and (2) that voting practices and procedures that have discriminatory results perpetuate the effects of past purposeful discrimination." S. REP. NO. 417 , supra note 88 , at 40 (footnote omitted).

95. The Voting Amendments of 1982 also provide precedent for congressional efforts to remedy the effects of past discrimination. The drafters of amended section 2 specifically stated that one of the aims of the legislation was to eliminate systems that perpetuate the effects of past discrimination. See S. REP. No. 417 , supra note 88, at 40; H.R. REP. No. 227, 97 th Cong., 1st Sess. 19 (1981).

96. See, e.g., S. REP. No. 417, supra note 88 ("Congress cannot alter the judicial interpretations in Bolden of the Fourteenth and Fifteenth Amendments by simple statute. But the proposed amendment to section 2 does not seek to reverse the Court's constitutional interpretation. Rather, the proposal is a proper statutory exercise of Congress' enforcement power ... . and it is not a redefinition of the scope of the Constitutional provisions.").

97. City of Mobile v. Bolden, 446 U.S. 55, 61 (1980).

98. Id. at 65-66. 
pretation which the Court had rejected. ${ }^{99}$ Such a clear override of a judicial standard must be accurately characterized: Congress, in effect, if not in name, overruled a Supreme Court interpretation of the Fourteenth and Fifteenth Amendments. ${ }^{100}$

\section{Power to Use Race-Based Remedies}

The proposed legislation might be challenged as violative of equal protection in that it advantages and disadvantages particular groups on the basis of race. The claim would be that the Constitution mandates a strictly color-blind interpretation of equal protection wherein there can never be disparate treatment on the basis of one's race. ${ }^{101}$ However, the need to redress the effects of past discrimination continues, ${ }^{102}$ the equal protection clause permits such redress, ${ }^{103}$ and if Congress determines that race-based remedies are the only effective means to enforce equal protection guarantees, it may rely on its unique section 5 remedial powers to do so. ${ }^{104}$

99. See Parker, The "Results" Test of Section 2 of the Voting Rights Act: Abandoning the Intent Standard, 69 VA. L. REV. 715, 764 (1983) ("Congress, in amending section 2 of the Voting Rights Act, has acted to overrule the Bolden plurality's requirement that discriminatory intent be proved to establish a violation.").

100. It might be argued also that the Civil Rights Act of 1990, which sought to modify the Court's holdings in Patterson v. McLean Credit Union, 109 S. Ct. 2363 (1989), Wards Cove Packing Co. V. Atonio, 109 S. Ct. 2115 (1989), Lorance v. AT\&T Technologies, 109 S. Ct. 2261 (1989), Martin v. Wilks, 109 S. Ct. 2180 (1989), and Price Waterhouse v. Hopkins, 109 S. Ct. 1775 (1989), if it had passed, might have provided additional support for the override of a judicial constitutional interpretation by Congress. See 136 Cong. Rec. S1522 (daily ed. Feb. 22, 1990) (statement of Sen. Hatch); 136 Cong. Rec. E229 (daily ed. Feb. 7 1990) (statement of Rep. Hawkins). However, the legislation affects only the statutory interpretation of Title VII; it does not attempt to provide an alternative interpretation of the Fourteenth Amendment. Id.

101. See Croson, 109 S. Ct. at 735 (Scalia, J., concurring in judgment) (applying color-blind approach to all racial classifications). But see Fullilove v. Klutznick, 448 U.S. 448, 482 (1980) ("[W]e reject the contention that in the remedial context the Congress must act in a wholly 'color-blind' fashion.); United Steelworkers v. Weber, 443 U.S. 193, 208 (1979) (affirmative action plan that reserved for Black employees $50 \%$ of the openings in plant's training program did not "unnecessarily trammel the interests of the white employees"); Regents of the Univ. of Cal. v. Bakke, 438 U.S. 265, 355 (1978) ("“[O]ur Constitution is color-blind" ... has never been adopted by this Court as the proper meaning of the Equal Protection Clause.") (Brennan, J., concurring in the judgement in part and dissenting in part).

102. See Local 28 of Sheet Metal Workers v. EEOC, 478 U.S. 421,450 (1986) ("Affirmative action 'promptly operates to change the outward and visible signs of yesterday's racial distinctions and thus, to provide an impetus to the process of dismantling the barriers, psychological or otherwise, erected by past practices.' ") (citing NAACP v. Allen, 493 F.2d 614, 621 (5th Cir. 1974)); Wygant v. Jackson Bd. of Educ., 476 U.S. 279, 280 (1986) (Court recognized that race-based remedies may be necessary to eradicate effects of prior discrimination even though it found program in Wygant to be invalid).

103. Fullilove, 448 U.S. at 477 ("congressional authority extends beyond the prohibition of purposeful discrimination to encompass state action that has discriminatory impact perpetuating the effects of past discrimination") (citation omitted); City of Rome v. U.S., 446 U.S. 156, 176 (1980) ("Congress may, under the authority of [the enforcement provision of] the Fifteenth Amendment, prohibit state action that, though in itself is not violative of $\$ 1$, perpetuates the effects of past discrimination.").

104. See Fullilove, 448 U.S. at 483 ("It is fundamental that in no organ of government, state or federal, does there repose a more comprehensive remedial power than in Congress, expressly charged with competence and authority to enforce equal protection guarantees."). 
Enforcement requires the imposition of a remedy. The Court has used racebased remedies for its own enforcement efforts. ${ }^{105}$ Congressional enforcement power explictly granted by the Fourteenth Amendment must at a minimum be co-equal with the Court's. ${ }^{106}$ Therefore, Congress should be equally able to impose race-based remedial programs.

The Court acknowledged that Congress possesses the authority to adopt such a remedy. In Fullilove, the Court upheld congressional race-based setasides for federal construction contracts based on Congress' special section 5 powers. ${ }^{107}$ Moreover, in Croson, Justice O'Connor reaffirmed congressional authority to adopt race-based set-aside programs based on "the unique remedial powers of Congress under section 5."108

In Metro Broadcasting, Inc. v. FCC, ${ }^{109}$ the Court once again accepted Congress' authority under the Fourteenth Amendment to adopt programs that employ benign racial classifications to redress past discrimination based on independent criteria. In addition, the Court reaffirmed Congress' section 5 enforcement power: "Congress [is] a co-equal branch charged by the Constitution with the power to ... 'enforce, by appropriate legislation,' the equal protection guarantees of the Fourteenth Amendment."

The Court's determination that a state's race-based program is unconstitutional does not preclude Congress from independently sanctioning a similar race-based program under its section 5 enforcement powers. ${ }^{11}$ For example, in Lassiter v. Northampton Election Board ${ }^{112}$ the Court found literacy tests to be permissible under section 1. However, Congress interpreted section 1 to prohibit literacy tests and legislated accordingly. In Morgan, the Court upheld Congress' interpretation, thereby supporting congressional authority to independently interpret and enforce the Fourteenth Amendment, even after the judiciary had rejected the same interpretation. ${ }^{113}$ Thus, Congress may interpret section 1 to permit the adoption of MBE programs even where the Court has previously rejected this interpretation.

In summary, Congress' section 5 enforcement powers place the federal legislative branch in a pseudo-judicial role, permitting Congress to prohibit

105. See Swann v. Charlotte-Mecklenburg Bd. of Educ., 402 U.S. 1 (1971) (imposing a race-conscious remedy to redress discrimination).

106. See Bohrer, supra note 60, at 494 ("Congress' power to enforce section 1 is no more limited than that approved for judicial use.").

107. Fullilove, 448 U.S. at 483.

108. Croson, $109 \mathrm{~S}$. Ct. at 718.

109. 58 U.S.L.W. 5053, 5057 (1990) ("We hold that benign race-conscious measures mandated by Congress-even if those measures are not "remedial" in the sense of being designed to compensate victims of past governmental or societal discrimination-are constitutionally permissible to the extent that they serve important governmental objectives within the power of Congress and are substantially related to achievement of those objectives.") (footnote omitted).

110. Id. (citing Fullilove, 448 U.S. at 472).

111. See Bohrer, supra note 60 , at 495 .

112. 360 U.S. 45 (1959).

113. Morgan, 384 U.S. at 648. 
discrimination on the basis of race, to determine where discrimination exists, and to design remedies to redress the effects of such discrimination.

\section{Power to Compel State Action}

Congress has a mandate under the Fourteenth Amendment to eliminate discrimination that it identifies. Once the decision is made to adopt a national legislative solution to allow states to redress the continuing effects of discrimination, it is natural that Congress would take the next step and compel state compliance where discrimination is found to exist. ${ }^{114}$ States might challenge this aspect of the legislation on the grounds that it infringes on powers reserved to the states by the Tenth Amendment. However, there is little basis for such a claim given that the Fourteenth Amendment was adopted specifically to protect individual rights against state infringement. ${ }^{115}$ That is, the Fourteenth Amendment was adopted with the specific intent to limit state power in relation to the perpetuation of discrimination on the basis of race..$^{116}$

In Missouri v. Jenkins, ${ }^{117}$ the Supreme Court addressed the balance to be drawn between state autonomy under the Tenth Amendment and state compliance with the Fourteenth Amendment. The Court held that a local school district could be "ordered [by a court] to levy taxes ... . in order to compel the discharge of an obligation imposed on [it] by the Fourteenth Amendment."118 The state of Missouri had maintained that such an order exceeded the Court's Article III remedial powers. ${ }^{119}$ However, the decision clearly established that the authority to require affirmative state action with respect to a governmental function typically reserved to state discretion under the Tenth Amendmentnamely the taxing of real property-fell within the bounds of judicial power, where the Court mandated such action to enforce the Fourteenth Amend-

114. The proposed statute can be adapted either to compel states to adopt race-based remedies where discriminatory impact is found to exist or merely to permit the use of race-based programs to alleviate the effects of past discrimination. If the goal of Congress is to compel the use of MBE set-asides, the word "shall" can be subsituted in the statute for the word "may." The relevant substitution points are indicated in the proposed legislation by a bracketed "[shall]" following "may." The bracketed portion of subsection (c) would be added where the statute compels states to adopt MBE set-aside programs.

115. See EEOC v. Wyoming, 460 U.S. 226, 243 n.18 (1983) (Fourteenth Amendment section 5 powers override state autonomy embodied in the Tenth Amendment); United States v. Marengo County Comm'n, 731 F.2d 1546, 1561 (11th Cir. 1984), cert. denied 469 U.S. 976"(1984) ("By their very nature [the Civil War Amendments] plainly empowered the federal government to intervene in state and local affairs to protect the rights of minorities newly granted citizenship."); G. STONE, L. SEIDMAN, C. SUNSTEIN \& M. TUSHNET, CONSTITUTIONAL LAW 447 (1986) (The "primary impetus for passage of the fourteenth amendment was the need to provide a basis for federal legislative action against the states.") (emphasis in original); Bohrer, supra note 60 , at 480 .

116. "The Civil War Amendments themselves worked a dramatic change in the balance between congressional and state power over matters of race." Croson, $109 \mathrm{~S}$. Ct. at 719.

117. 110 S. Ct. 1651 (1990).

118. Id. at 1666 .

119. Id. at 1665 . 
ment. ${ }^{120}$ The Court went beyond merely prohibiting unlawful conduct and imposed a remedy which required the state to implement a new system of taxation previously unauthorized under Missouri law.

Congressional enforcement power explicitly granted by the Fourteenth Amendment is co-equal with the Court's. ${ }^{121}$ Given that the enforcement powers of Congress and the Supreme Court are coextensive, Congress has the same authority as that granted to the Court in Jenkins to order states to implement actions which would otherwise be reserved to the nondelegated powers of the states under the Tenth Amendment. The federal government's authority to employ race-based remedies to redress past discrimination, ${ }^{122}$ combined with the general subordination of Tenth Amendment powers to the maintenance of equal protection guarantees under the Fourteenth Amendment, ${ }^{123}$ permits a federally mandated MBE set-aside program. The proposed legislation would not overstep the bounds of congressional authority to regulate state practices in the allocation of government contracts.

\section{CONCLuSION}

The proposed legislation will correct the conflict inherent in the Croson decision. While the legislation relies upon directives extracted from both Croson and Fullilove, it may override Croson in that it replaces the Court's "qualified contractors" standard for establishing specific discrimination with a more inclusive test. The authority for a congressional override of Croson derives from the special enforcement powers delegated to Congress in section 5 of the Fourteenth Amendment. Congress previously exercised this independent section 5 power to override a judicial standard when it adopted the Voting Rights Act Amendments of $1982 .{ }^{124}$ Implementation of the proposed statute would simply build on this precedent. The proposed federal legislative answer to Croson would further the ideals of equal protection by allowing a broader application of race-based remedies to correct the effects of past discrimination.

120. Id. at 1666 ("IS]tate policy must give way when it operates to hinder vindication of federal constitutional guarantees") (citing North Carolina Bd. of Educ. v. Swann, 402 U.S. 43, 45 (1971)).

121. See supra note 106 and accompanying text.

122. See Fullilove, 448 U.S. at 448.

123. Pennsylvania v. Union Gas Co., 109 S. Ct. 2273, 2302 (1989) ("The Fourteenth Amendment . . . was avowedly directed against the power of the States.") (Scalia, J., concurring in part and dissenting in part).

124. Pub. L. No. 97-205, 96 Stat. 131 (codified as amended at 42 U.S.C. $\$ \S 1973$, 1973b, 1973aa-1a, 1973aa-6 (1982)). 